\title{
AN EXPLORATORY RESEARCH REGARDING ROMANIAN MARKET FOR HALAL FOOD
}

Valentin-Cosmin SARACIN

Bucharest University of Economic Studies saracin_valentin@yahoo.com

Adrian VASILE

Bucharest University of Economic Studies

Ahmed HARRATI

Mohammed V University (Rabat, Morocco)

\begin{abstract}
The changes in the social structure, the economic crisis, the ageing of the population had an important role in the development of Romania. As a result, Romania must identify other segments and industries in order to rejuvenate the economy of the country. This study focuses on a market niche represented by Halal food products, which are underdeveloped in Romania at this moment. It may represent a potential catalyst for the development of other latent sectors and may consolidate the bilateral relations with the Muslim countries, in conformity with the globalization and the internalization of the global market. The research method used in this study is the thorough analysis of numerous scientific articles and a literature review. It focuses both on the past and the current state of Halal food products and how the development of this market niche can lead to the expansion of other sectors, such as tourism and education.
\end{abstract}

Keywords: halal, Muslim, certification, logo, education, economy

JEL Classification: $\mathrm{I}_{25}, \mathrm{M}_{31}, \mathrm{P}_{40}, \mathrm{Z}_{12}$

\section{Introduction}

The most important country in Halal industry in the world, part of the top 10 ranking, is Malaysia, according to Bohari, Hin and Fuad in "the competitiveness of Halal food industry A SWOT - ICT analysis. In Malaysia there is a developmental body, which is the only government-mandated company in the world, task with coordinating and developing the national Halal industry. Actually HDC is a brand, which has the ability to make things happen, steered by experts delivering worldclass know-how and collaborative by working towards a win-win situation. This is the only country in the world where the government provides full support in promoting the Halal Certification process on products and services. There are some countries where the Certification process is developed at the level of individual provinces or only non-governmental organizations. 
Halal Certification is actually the assurance to all Muslim consumers worldwide, because it fulfilled the Sharia law, which is a must for all Muslim population. To other people, Halal products are above average quality products. According to HDC, all the operators who want to be certificated must comply with GMP (Good Manufacturing Practice) and HACCP requirements. The Malaysia Halal logo is recognized and well-accepted, world-wide, because The Malaysia Certification procedures and Malaysian Halal Standards are the most utilized world-wide, as they received recognition for maintaining excellence in Halal industry.

Romania is a developing country, so the vision the country should have does not depend on a single sector but by various economic generators that can contribute to the country's wealth and economic growth. Since this vision should be one of the most important and significant objectives of the country, Halal foodproducts sector must be seen as a milestone in the economic growth. This industry is gaining its popularity day by day and opens up opportunities so producers can expand their target market internationally. Consumer demand on food has also changed considerably, so Halal sector should not be ignored due to the 64.130 Muslim citizens in Romania in 2012, according to INS Bucharest and due to higher demand for Halal products in the international market, that can increase exports, and thus, there will be a higher added value for suppliers. The meaning of the food is defined as anything that can be eaten or taken orally to the body, in order to gain energy and to sustain life. A common need among people is the food, so the market potential is even more promising through people from different religion and culture who have different experience and perceptions to some specific food. Nowadays, in our society, there is an increasing concern over health, which promotes the idea of consuming fresh and healthy food products, and Halal food is the answer to this idea, because it covers the whole understanding of consuming hygienic and clean food, for a better life. Today, consumers are searching for food that can keep them healthy, in a better mental state and for growing their life quality. In Islam countries, Halal food is associated with religion. The most important thing that can give assurance over a Halal product is the Halal logo, which gives to the Muslim consumers the assurance needed, that the food product is produced and prepared according to Islamic laws. Furthermore, non-Muslim consumers understand the Halal logo as the assurance over a health and a clean product and hygienic way that the product has been produced. It has been proven that non-Muslim consumers do respond positively to Halal food certification, according to Vloreen, Ardiana, Siti, in "Acceptance on Halal food among Non-Muslims Consumers" (2014).

There is no doubt that Muslim consumers accept the Halal food as shown in studies on this food consumption. Nevertheless there are not too many studies regarding the degree of acceptance of this food by non-Muslim consumers. Nowadays, the Muslim countries' Halal markets show an increasing interest and concern of Muslims population for what food they consume, given their religious obligations. It is also a fact that more and more non-Muslim people with a wide ethnic and cultural background are interested in this kind of food. At global level, Halal industry tends to be fragmented with numerous standards. According to the 
scientific literature there is a global opinion of uniting the Halal standards witch have a serious impact over the traceability of the final product.

This study will explore the Muslim' situation and the Halal market in Romania, the characteristics of the Halal credentials providing information relating to acceptance on Halal food, and the need of exploration this sector, for an economic growth.

\section{Literature review}

The Halal production represents the action of breeding and exploiting animals, birds, fish, as well as obtaining agro-food products without using the means and technologies qualified as prohibited by the Islam religion. They are called "Halal", in conformity with the canons, the rules and religious criteria established by the Islamic religion, which respects the standards, the procedures and the national and international specifications and are certificated by an inspection authority commissioned specifically for that purpose.

In the Quran, Halal means permitted or lawful so Halal food means the permissible food that can be eaten without hesitation. In "Kosher and Halal: religious observances affecting dietary intakes" (2002), Eliasi and Dwyer sustained the idea that the food products are considered Halal or Haram by looking and monitoring the whole food chain. One food product is considered Haram also if the source is Haram, and has the potential to harm the body, the mind, the soul and the religion of a person. Halal can also represent the expression witch indicate the permission by Islamic religion to consume or utilize certain things. Regarding an animal, Halal means that the animal has been slaughtered in accordance with Sharia law, which means that it does not contain anything witch is considered to be impure according to Sharia law. Regarding food items, it means that it has not been prepared, processed or manufactured using instruments or ingredients that are forbidden according to Sharia law. Moreover, during the course of the preparation processing or storage the product has not been in contact or close proximity with forbidden things. Therefore, in Islam, all foods are considered Halal, except the following, which are Haram: swine or pork, and its by-products, animals witch are slaughtered improperly or dead before being slaughtered, animals witch are killed in the name of anyone else except Allah, and drinks like for example alcohol.

According to Badruldin in 'Clients' perception towards JAKIM service quality in Halal certification" (2011), Halal certification means the examinations of food processes like preparation, slaughtering, ingredients used, cleaning, handling, processing, storage, transportation and distribution, which can be obtained when the food has been verified and prepared from permissible ingredients in a clean and hygienic manner. The process of Halal Certification is like an industrial convention, a mechanism of coordination and quality that may be used to offer for their consumers a better quality. The concept of Halal is intangible and credence, and the system is governed by domestic and civic conventions.

The confidence of consumers is often given by the logo, but in many cases, for example, in "Credence quality coordination and consumers' willingness-to-pay 
for certified Halal labelled meat", Verbeke, Rutsaert, Bonne, and Vermeir showed that consumers can buy at the Islamic butcher, even without the Halal logo witch certificates the products, so that it indicates that the consumers do trust the products through personal interaction, with strong preference to deal with individual of known reputation.

In general, Halal concept is associated with green colour, which indicates the hygienic, quality, safety over something. Moreover, the green colour signifies in management, the low negative impact of human activities towards the environment. Common point between green colour, management, and Halal certification, are presented by Razalli, Abdullah and Yusoff "Is Halal certification process "green." (2012), who emphasized on waste management, education, water in terms of supply and drainage and lastly energy in terms of ceiling, lighting, ventilation and temperature.

The Halal concept was not that well known, until recently. This market is extremely dynamic and attractive, representing a remarkable opportunity for the potential Romanian exporters, because the Halal market owns $12 \%$ of the worldwide agro-food business. Considering the high level of the economy, the Gulf region is the biggest global importer of Halal food, especially Halal meat. Among the most important marketplaces for the Halal food in the Middle East stand Saudi Arabia and the United Arab Emirates. Currently, Brazil, USA and the European Union are the biggest suppliers from the Gulf region, owning 63\% of the imports in that area.

The nutritional Halal standards for production, logistics and commerce are respected, according to the Sharia law, which determine what is allowed and what is forbidden for a Muslim. As an example, the Christians need to know that the Halal meat is obtained from animals sacrificed by adult men and/or Muslim priests, who invoke a certain prayer from the Quran, respecting a strict ritual. The Halal market not only includes meat, but pastry, syrup, dairy products, even cosmetics and certain services, like the Halal Hotels, where the consumption of alcohol is strictly forbidden.

Halal certification is important for consumers, because it increase the confidence in those products. The results of Al-Nahdi and Islam in "Factors influencing Malaysian Muslims to patronage Halal restaurants - Ambience as a mediator" (2011) showed that that perceived behaviour control is the most influential component that influence Malaysian Muslims to support Halal restaurants. According to this there is a growing number of restaurants operators witch want Halal Certification, in order to gain more customers.

In Romania, there are a lot of Muslim entrepreneurs who provide Halal food, but the non-Muslim entrepreneurs are also encouraged to provide Halal food and seek Halal Certification because of the following reasons: Firstly, the Halal logo is anywhere seen as a sign of confidence. Secondly, Halal certification helps Muslims to make a safe choice over one product, according to Habib in "Halal cert a passport to successes'. Moreover, Halal certification brings the certitude that the products not only fulfil Halal requirements, but also are in accordance with strict hygiene practices (HACCP) - hence quality products. 
A brand strategy gives a major edge in increasing competitive markets. The brand is like a promise to the costumer. It tells them what they can expect from products or services, and what differentiates your products from that of your competitor. The foundation of a brand is a logo. Halal logo on a product represents the assurance for Muslim people that the food can be consumed with confidence. All the same, just the Halal logo on the product or just the stamp is not enough. According to Caswell in "Quality assurance, information tracking, and consumer labelling", labelling is important and it pays a significant role by providing necessary information for the customers in making purchasing decisions. It is a must that in addition to Halal logo there must be a label, because the consumer also seek information on product ingredients (Dali, Sulaiman, Samad, Ismail, \& Alwi, "Halal products from the consumer perception: An online survey" (2007)). The credibility of the quality needs to be clearly informed through an indication on label, because Halal concept refers to its origins, the nature and processing method.

\section{The Halal market in Romania}

\section{The Muslim population and their needs}

At the moment, in Romania there are many religious cults and the Muslims, among the other citizens, practice freely their religion, according the Quran knowledge. Islam represents one of the greatest contemporary religions, comprising over a billion believers. In Romania, the Islamic population gathers different nationalities, like Turks, Tatars and Albanians. Islam appeared in Romania in the XIII ${ }^{\text {th }}$ century, due to the Turk and Tatar population. In 1241, the Tatars settled in different regions near the Carpathian Mountains.

During 1262-1264, the emperor Mihai the XIII ${ }^{\text {th }}$ gave to Izettin Keyaus and Saru Saltâk Dede the right to settle their military camp in Dobrogea, having the mission to defend the Byzantium from the northern invasions. This is how the Turks appeared in the region now called Babadag. The first stable Muslim communities on our territory were built in the XIV-XV ${ }^{\text {th }}$ century, as a result of the Ottomans ruling over the Romanian Principalities, but they developed mostly in Dobrogea and some areas across the Danube.

In 1877, the Muslim Cult from Romania, the first one who united the Muslim community, was organised in 5 Muftis. Between the two World Wide Wars, they united and formed 2 and, in 1943, the Muftis from Tulcea and Constanta merged into a Mufti that has the headquarters in Constanta. The religious activity is led by a "Mufti", which is chosen by secret ballot. There is a synodic board as well, called Sura Islam, which has a consultative vote, 23 members and gathers periodically to solve the cult's administrative and disciplinary issues.

In Romania, there are approximately 64.130 Muslim citizens (in 2011), according to INS Bucharest, and the majority live in Constanta, some of them in Tulcea and the rest in cities like Bucharest, Braila, Galati, Calarasi, Giurgiu.

The Romanian companies do not participate much in the development of this sector in Romania, if we were to compare it to the other countries internationally. Nevertheless, the internal market has registered a higher consumption of Halal 
food, because of the significant number of Muslim people living in Romania (64.130, according to the 2011 Census). The Halal sector plays an important part in the global market and for the Romanian companies becomes more and more interested in exploiting this new market.

The retail trade for the Muslim agro-foods was postponed in our country because the lack of knowledge of this segment's revenues, as well as the behaviour of the consumers. In addition, there is a major confusion between the Halal specifications and the authentication, as well as a lack of necessary logistics for the development of this market, which lead to difficulties in exploiting this market.

There are 21 categories of religions in our country, as seen in the table below.

Table no. 1. The trends of the believers' number as presented by the 1992, 2002, and 2012 census, for the legal religions in Romania

\begin{tabular}{|c|c|c|c|}
\hline & $\mathbf{1 9 9 2}$ & $\mathbf{2 0 0 2}$ & $\mathbf{2 0 1 2}$ \\
\hline Population & $\mathbf{2 2 . 8 1 0 . 0 3 5}$ & $\mathbf{2 1 . 6 8 0 . 9 7 4}$ & $\mathbf{1 8 . 8 6 1 . 9 0 2}$ \\
\hline & $\mathbf{\%}$ & $\mathbf{\%}$ & $\mathbf{\%}$ \\
\hline Orthodox & 86,81 & 86,79 & 86,45 \\
\hline Catholic & 5,09 & 4,73 & 4,62 \\
\hline Reformed & 3,52 & 3,23 & 3,19 \\
\hline Pentecostal & 0,97 & 1,50 & 1.92 \\
\hline Greek-catholic & 0.98 & 0.88 & 0.80 \\
\hline Baptist & 0.48 & 0.58 & 0.60 \\
\hline Adventist & 0.34 & 0.43 & 0.43 \\
\hline Muslim & 0.25 & 0.31 & 0.34 \\
\hline Others & 1.56 & 1.55 & 1.65 \\
\hline
\end{tabular}

Source: INS Bucharest www.insse.ro accessed on $3^{\text {rd }}$ of Febr.2015

According to the Table no 1, the population from Romania has decreased with 1.129.061 since 1992 until 2002. Moreover, since 2002 until 2012 the population has decreased with 2.819.072. In 1992 the Muslim population was $0.25 \%$ of the total population in Romania and in 2002, it increased to $0.31 \%$. According to the 2011 Census, in Romania there were $0.34 \%$ of the total population. According to these facts, we can see that the number grew significantly, as well as the demand. At the same time, in 2012 there is an important number of Muslim people in Romania relating to the total population of approximately 18.86 million people, compared with the total amount of 21.6 million from 2002. 


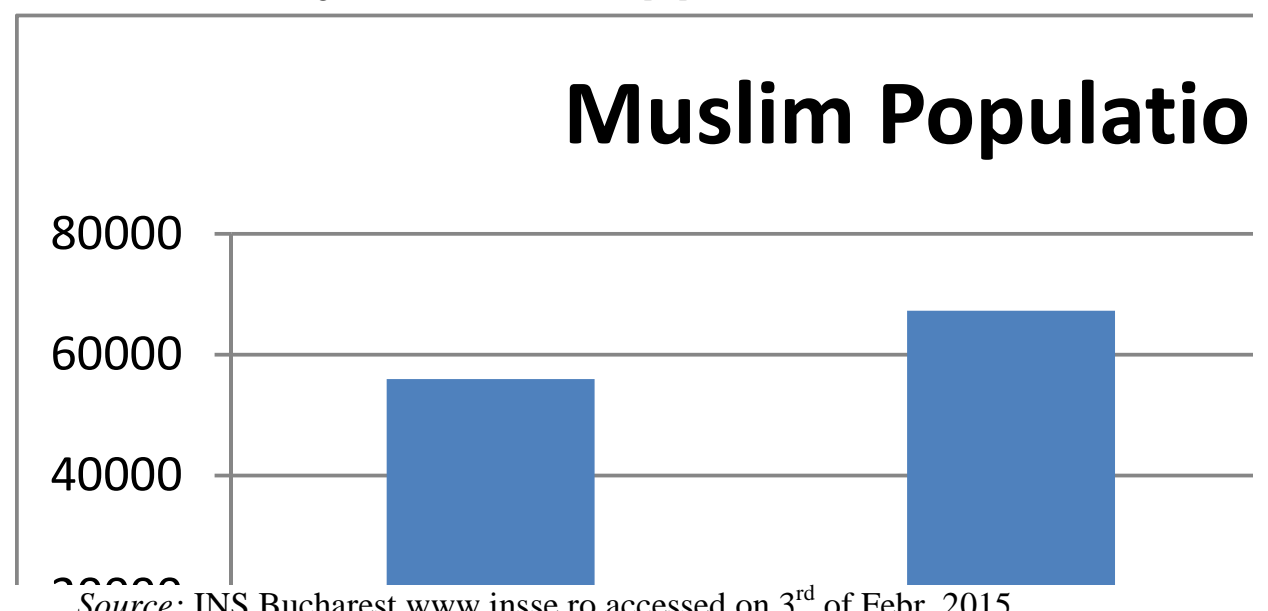

Source: INS Bucharest www.insse.ro accessed on $3^{\text {rd }}$ of Febr. 2015

Figure 1 shows that in 1992, the Muslim population was 57.025 and in 2002; it grew to 67.211. According to the 2011 Census, in Romania there are 64.130 Muslim people, which represent $0.34 \%$ of the total amount. According to these facts, we can see that the number grew significantly, as well as the demand.

Figure no. 2. Romania Population - 2012

\section{Romania Population - 20}

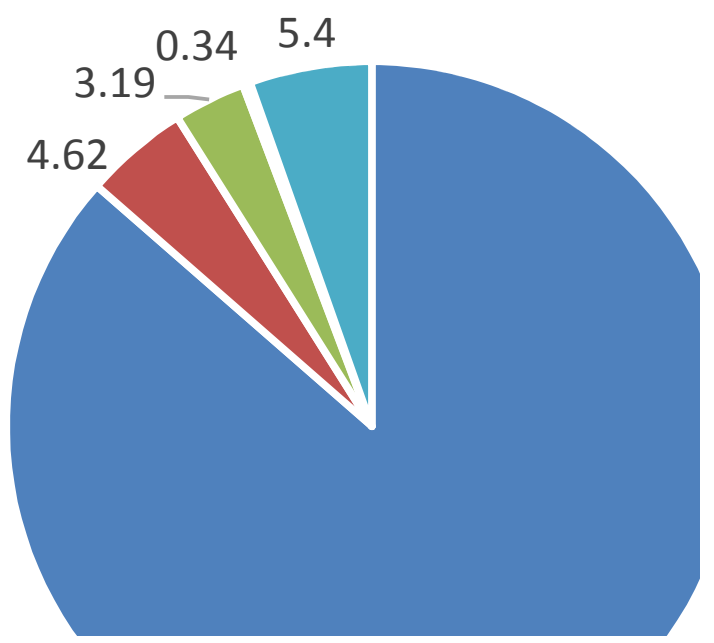

Source: INS Bucharest www.insse.ro accessed on $3^{\text {rd }}$ of Febr. 2015 
Figure no 2 shows that in 2012, in our country there were $86.45 \%$ Orthodox people, $4.62 \%$ - Catholic people, $3.19 \%$ - Reformed people, $0.34 \%$ Muslim people, and 5.4\% - other religions.

In Romania, there are plenty of Halal shops, which offer chicken, beef, sheep, and spices, most of them being located in Bucharest or Dobrogea. Except for these Halal shops, the consumers are individual customers of the specific restaurants. Generally, the Romanian Muslims cook at home (as an example, the ones who live in the rural areas shop a lot) or they eat out in restaurants who serve Muslim food.

\section{Halal certification}

The concept of Halal is associated with the religious belief, and as a result, it's difficult to develop a safe indemnification system. According to the consumers, it is difficult to evaluate and verify if a product is Halal or Haram. Because of that, the consumer must trust the provider and the information written on the labels.

Currently in Romania there is no certain law for the Halal inspection and certification. The Muslim consumers from Romania desire and affirm the need of a legal motion which could bring under regulation the Halal market from Romania. This strategy implies organising and developing an inspection and certification authority for Halal agro-foods, accredited by the Romanian Mufti, the only acknowledged entity who regularises the Halal market internationally. The Halal accreditation offers a subsidiary vouch for the consumer.

Internationally, there are estimated to be 122 Halal certifications. Globally, there has been intent to unify the Halal standards by the OCI. The United Arab Emirates had the task to produce a unified standard which should have been applied in all the 57 Islam countries. This initiative was unwelcomed. Nevertheless, many specialists consider that this strategy could lead to a higher development of this market, helping the consumers, by facilitating the exports to the consumer countries.

\section{The response of the Romanian producers}

Apparently, the Romanian companies are beginning to exploit this sector, which is increasing progressively. At the moment, the Romanian producers and the traders are not very interested in producing Halal agro-food because of various reasons:

- Halal represents a problem, being associated with the Muslim religion. Our nation had numerous difficulties with the Ottoman Empire and the Romanian producers see the concept of Halal as a complexity and an outrageous strictness. As a result, they did not proceed in developing this sector.

- The Halal industry represents a great potential globally. As a result, the modern ways of Halal production, commerce and consumption are developing, due to the increasing number of Muslim people. On the other hand, most of the agrofood is concentrated on the internal market. The lack of knowledge in this matter represents an impediment in accessing this sector, because they lack the basic 42 
knowledge of what exactly Halal means. It would be a challenge for the Romanian companies to enter this market, because the Romanian culture is mostly associated with Haram (forbidden products, like the pork meat and alcoholic beverages).

- The Halal concept can apply to the finite product, as well as to the process of obtaining the finite product. This matter needs a major reappraisal for each and every company, in order to coordinate the production, as well as complementary investments. As a result, the Romanian producers avoid the risks and tend to choose a more secure market to exploit.

- The Romanian consumers don't have the necessary acknowledgement regarding the Halal products, but there has not been an awareness motion over this matter either. Most of the Romanians do not know much about the Halal concept and are not interested to learn. This matter certainly makes less motivated the other potential producers.

The competition between the Romanian companies becomes more and more acerbic, resulting in them looking for alternatives. As a conclusion, exploiting the Halal market will not mean higher costs, but higher income.

Romania depended on certain sectors, like the automobile industry, the metallurgic sector, which implied using mostly all the existing working force. Currently, Romania must bloom in the industries which could lead to a significant amount of foreign currency. A plan is needed for participating in promising sectors, like education and tourism.

\section{Education}

Generally, a Muslim community revolves around a mosque, which represents the place where group rituals are being held. After 1989, considering the reorienting to the European values according the right to free thinking and expressing the religious beliefs, the Muslims from Bucharest associated in different non-governmental organisations. This is how a true Muslim civil society was born, whose efforts materialized in building the first mosque in Bucharest in 1994, the Ar Rahman Mosque.

Besides the Ar Rahman Mosque, there is the Ar Rahman School and, besides the Muslim League Mosque, there is the Jerusalem School. In Romania, there are other schools which are not destined exclusively to the citizens of their specific countries; the Jordanian School, the Syrian School, the Palestinian School, the Lebanese School.

The mosques, the schools and the cultural institutions are mostly attended by Arabian residents from Iran, Pakistan, Indonesia, Malaysia, etc. Nevertheless, the Muslim communities don't practice an aggressive policy and are not propaganda institutions.

The success of a Halal certified product is based on how well the consumers understand the principles of HALAL and its benefits to the consumers. By educating the consumers, the consuming of Halal food will increase, not only for Muslims, but also for non-Muslims as well. The consumers also need to understand the procedures of Halal food certification and its benefits, the credibility of Halal 
logo though understanding procedures of post certification, the guarantee of health and safety Halal products.

Romania has always been a destination chosen by the worldwide tourists, because of its uniqueness culture and the amazing sights. For example, in 2012, the Romanian tourism has registered a number of $1.514,8$ of foreigners, less tourists compared to the year of 2011, when there have been 1.653,4 (according to INS Bucharest).

An important number of Muslim tourists come to Romania every year, and the lack of availability of Halal food is an issue noticed by many people. The Muslim tourists cannot tell for sure if the products we offer are Halal or not. Because of that, the tourists would rather bring their food from home or will only eat at the restaurants which serve Halal food, not choosing our local foods. During the Ramadan, the Romanian hotels are not prepared as they should for the Muslim guests. There are other things the tourists want when they come to Romania, for example excellent services, touristic religious services etc.

\section{Conclusions}

Considering our history, the Islam religion has amplified and developed a lot in time, but the awareness regarding the Muslim needs is still low in Romania. This essay explores and comes up with some arguments and perspectives for the Halal market potential, in order to be developed, as an alternative sector for the industrialization and globalization. Regarding all these aspects, the Romanian society has to make an effort to understand the Halal concept, which can lead to the expansion of our education and tourism. In addition, many researches should be made in order to raise the awareness over this notion and to help to develop this sector.

From literature review, the results show that educational program and marketing tool are the most important mechanism to promote and sustain the Halal sector. Both the entrepreneurs and consumers need to be educated on the Halal concept and procedures, to develop the understanding of Halal production and its benefits, by various channels which enhance their knowledge. Both the operators and the government should play different roles with the common goal of achieving the consumer aware of the significance Halal food consumption, and to increase the exports in Muslim countries.

In order to increase the economic sector of Romania, government should sustain and develop the Halal sector, because of the number of Muslims who are living here, and after the Malaysia example, Romania can become a Halal hub, because we have enough resources of animals to develop the Halal food sector, in order to increase our exports and to consolidate the bilateral relations with the Muslim countries. 


\section{References}

Al-Nahdi T. S. M., Islam M. A., "Factors influencing Malaysian Muslims to patronage Halal restaurants - Ambience as a mediator' - Business Review (2011), pp. 121-133; http://www.academia.edu/9444320/Factors_Influencing_the_Intention_to_Purchase_ Real_Estate_in_Saudi_Arabia [Accessed December 5, 2014].

Badruldin B. Mohamed Z., Sharifuddin J., Rezai G., Abdullah, A. M., Latif I. A., "Clients' perception towards JAKIM service quality in Halal certification" - Journal of Islamic Marketing (2012), pp. 59-71; http:// www.emeraldinsight.com/17590833.htm [Accessed December 5, 2014].

Bohari A. M., Hin C. W., Fuad, N., "The competitiveness of halal food industry in Malaysia: A SWOT - ICT analysis" - Journal of Society and Space (2013), pp. 1-9; http://www.ukm.my/geografia/images/upload/1.geografia-jan\%202013-manaf-edam $\%$ 20\%281-9\%291.pdf [Accessed December 5, 2014].

Caswell, J. A, "Quality assurance, information tracking, and consumer labelling" - Marine pollution bulletin (2006), pp. 650-656; http://www.ncbi.nlm.nih.gov/pubmed/ 16996544 [Accessed December 7, 2014].

Dali N. R. S. M., Sulaiman S., Samad A. A., Ismail N., Alwi S. H., "Halal products from the consumer perception: An online survey" - US National Library of Medicine (2006), pp. 650-656; http://www.ncbi.nlm.nih.gov/pubmed/16996544 [Accessed December 9, 2014].

Eliasi Jr., Dwyer Jt., "Kosher and Halal: religious observances affecting dietary intakes" US National Library of Medicine (2002), pp. 911-913; http://www.ncbi.nlm.nih.gov/ pubmed/12146548 [Accessed December 9, 2014].

Habib S., "Halal cert a passport to success" - The Star Online (2012); http://thestar.com.my/news/story.asp?file=/2012/4/15/nation/20120415071025\&sec= nation [Accessed December 9, 2014].

Mahiah Said et al, "Conceptual Framework on Halal Food Supply Chain Integrity Enhancement', Procedia - Social and Behavioral Sciences 130 (2014) pp. 120-128; http://www.sciencedirect.com/science/article/pii/S1877042814011252 [Accessed November 15, 2014].

Mariatul A. J., Rosidah M., "Determinants of Attitude towards Islamic Financing among Halal-certified Micro and SMEs: A Preliminary Investigation' - Procedia - Social and Behavioral Sciences 130 (2014) pp. 135-144; http://www.sciencedirect.com/ science/article/pii/S1877042814029279 [Accessed November 15, 2014].

Mohd H. Z., Marhani M. A., Mohamed S. A., "Conceptual Framework on Halal Food Supply Chain Integrity Enhancement' - Procedia - Social and Behavioral Sciences 121(2014), pp. 58-67; http://www.sciencedirect.com/science/article/pii/ S1877042814011252 [Accessed November 16, 2014].

Nurulhuda N., Nor L. M., Zainal S., "'Strategic Approach to Halal Certification System: An Ecosystem Perspective"' - Procedia - Social and Behavioral Sciences 121 (2014), pp. 79-95; http://www.sciencedirect.com/science/article/pii/S1877042814011276 [Accessed November 16, 2014].

Razalli M. R., Abdullah S., Yusoff R. Z. R. Z, "Is Halal certification process "green." In The 3rd International Conference on Technology and Operations Management (2012), pp. 23-30; http:// https://sites.google.com/site/razallirizal/me-1/mypublications [Accessed December 16, 2014].

Riaz, M., Chaudry, M., “Halal Food Production’, Hardcover: CRC Press, 2003. 
Shazlinda M. Y., Noriyuki S., "Halal Food Production" - Procedia - Social and Behavioral Sciences 121 (2014), pp. 253-261; http://www.sciencedirect.com/science/ article/pii/S1877042814011434 [Accessed November 22, 2014].

Mahiah S., Faridah H., Rosidah M., Rahman N., “Assessing Consumers' Perception, Knowledge and Religiosity on Malaysia's Halal Food Products" - Procedia - Social and Behavioral Sciences 130 (2014), pp. 120-128; http://www.sciencedirect.com/ science/article/pii/S1877042814029255 [Accessed November 22, 2014].

Shazlinfa M. Y., Noriyuki S., "The Development of Halal Food Market in Japan: An Exploratory Study" - Procedia - Social and Behavioral Sciences 121 (2014), pp. 253-261; http://www.sciencedirect.com/science/article/pii/S1877042814029255 [Accessed December 21, 2014].

Verbeke W., Rutsaert P., Bonne K., Vermeir I., "Credence quality coordination and consumers' willingness-to-pay for certified halal labelled meat', - US National Library of Medicine (2013), p. 790; http:// http://www.ncbi.nlm.nih.gov/pubmed/ 23688800 [Accessed December 21, 2014].

Vloreen N.M., Ardiana M., Siti N., "Acceptance on Halal food among Non-Muslims Consumers" - Procedia - Soial and Behavioral Sciences 121 (2014), pp. 262-271; http://www.sciencedirect.com/science/article/pii/S1877042814011446 [Accessed December 21, 2014]. 